\title{
PRAWA STRONY POSTĘPOWANIA W SPRAWIE PRZYMUSOWEJ RESTRUKTURYZACJI BANKU (RESOLUTION)
}

\author{
Katarzyna Chojecka \\ Wydział Prawa i Administracji, Uniwersytet Warszawski
}

\section{Streszczenie}

Artykuł stanowi analizę praw strony postępowania w sprawie przymusowej restrukturyzacji (resolution). Regulacja ta, ukształtowana w formie postępowania administracyjnego, służy usprawnieniu restrukturyzacji lub likwidacji podmiotów zagrożonych upadłością w taki sposób, by w miarę możliwości zmaksymalizować bilans aktywów zagrożonego podmiotu, ale i by w jak najmniejszy sposób zaangażować środki publiczne, a kosztami procedury obciążyć raczej akcjonariuszy i wierzycieli podmiotu. Mechanizm ten jest traktowany jako środek ostateczny, gdy wszelkie inne środki nie będą w stanie uchronić sektora przed ryzykiem kryzysu.

W ramach polskiej regulacji znacząco ograniczone zostały prawa strony postępowania administracyjnego. Przepisy wyłączają stosowanie zasady czynnego udziału stron w postępowaniu, możliwość wniesienia odwołania od decyzji oraz ograniczają możliwość otrzymania odszkodowania za nieprawidłową decyzję, jak też skracają terminy do zaskarżenia decyzji do sądu administracyjnego. Artykuł analizuje te restrykcje w kontekście celów resolution i zestawia je z możliwą niezgodnością przepisów z Konstytucją RP.

Słowa kluczowe: resolution, przymusowa restrukturyzacja, strona, postępowanie administracyjne, kryzys finansowy.

JEL Class: K23. 


\section{WPROWADZENIE}

Resolution, czyli przymusowa restrukturyzacja, powstała jako odpowiedź na doświadczenia kryzysu finansowego, którego szczyt przypadł na lata 2008 -2009. Wtedy też część banków zagrożonych kryzysem uznana została za „zbyt duże by upaść" (ang. too big to fail) i w konsekwencji musiała być ratowana z wykorzystaniem środków publicznych. Skutki takiego rozwiązania ponoszone były naturalnie przez budżety państw i w rezultacie przez podatników. Resolution $\mathrm{w}$ formie procedury administracyjnej prowadzonej przez niezależny organ, finansowanej ze środków prywatnych sektora bankowego jest zgodna z założeniem, że koszty złego zarządzania bankami i ryzykownych decyzji biznesowych prowadzących do kryzysu, powinny być ponoszone przez akcjonariuszy i wierzycieli zagrożonych instytucji. Ponadto, w kryzysowych sytuacjach, restrukturyzacja bądź likwidacja banków na podstawie standardowej procedury upadłościowej nie przynosiła pozytywnych rezultatów dla sektora - wartość zagrożonych podmiotów ulegała raczej minimalizacji niż jej maksymalizacji, a pożądanym efektem było przecież odzyskanie jak największej ilości aktywów, by móc zapewnić rynkowi płynność [Gleeson i Guynn 2016: 5]. Autorzy podsumowują również, że resolution może pełnić funkcję instrumentu, który przyczynia się do modyfikacji bilansów banków i ich wierzycieli w taki sposób, by koszt tego procederu był jak najniższy, a skutki dla systemu finansowego jak najmniej dotkliwe [Kozińska 2018: 44].

W Polsce resolution zostało wprowadzone Ustawą z dnia 10 kwietnia 2016 r. o Bankowym Funduszu Gwarancyjnym, systemie gwarantowania depozytów oraz przymusowej restrukturyzacji (dalej: ustawa o BFG) ${ }^{1}$, która stanowi implementację Dyrektywy PE i Rady 2014/59/UE z dnia 15 maja 2014 r. ustanawiającej ramy na potrzeby prowadzenia działań naprawczych oraz restrukturyzacji i uporządkowanej likwidacji w odniesieniu do instytucji kredytowych i firm inwestycyjnych (dalej: dyrektywa BRR). Rola organu resolution powierzona została Bankowemu Funduszowi Gwarancyjnemu.

Postępowanie administracyjne, w ramach którego prowadzona jest przymusowa restrukturyzacja banku, zostało znacząco zmodyfikowane w porównaniu ze standardową procedurą wynikającą z regulacji k.p.a. Warto tu przywołać art. 28 k.p.a. kształtujący zasadniczą pozycję strony w postępowaniu administra-

\footnotetext{
${ }^{1}$ Niektórzy autorzy wskazują, że resolution istniało w polskim systemie prawnym już w roku 1994, a za jej przykład podają uprawnienia Narodowego Banku Polskiego w stosunku do banków nieobjętych gwarancjami Skarbu Państwa. Nie można zgodzić się z tym stanowiskiem, gdyż resolution jest procedurą o określonych i skonkretyzowanych zasadach, wśród których naczelną z nich ma być przekierowanie kosztów utraty płynności banku na jego wierzycieli i akcjonariuszy. Sam fakt posiadania uprawnień do stosowania instrumentów stabilizujących wobec banków przez odpowiedni organ państwowy nie oznacza, że regulacja ta powinna nosić miano przymusowej restrukturyzacji - Por. Gronkiewicz-Waltz [2018: 653-659].
} 
cyjnym, na mocy którego stroną jest każdy, czyjego interesu prawnego lub obowiązku dotyczy postępowanie albo kto żąda czynności organu ze względu na swój interes prawny lub obowiązek. Zasadniczą kwestią jest tutaj, że przymiot bycia stroną postępowania opiera się na interesie prawnym, określanym jako osobisty, własny, indywidualny, konkretny i aktualny [Gołaszewski [w:] Hauser i Wierzbowski (red.) 2017: 219]. Pozycja prawna strony postępowania (ujętej w ustawie o BFG jako ten zagrożony podmiot, którego dotyczy restrukturyzacja) doznała szczególnej modyfikacji, a jej uprawnienia w postępowaniu zostały w dużej mierze ograniczone. Regulacja ta wydaje się uzasadniona z punktu widzenia nadrzędnych celów postępowania, tj. wynikających z art. 66 ustawy o BFG ,utrzymania stabilności finansowej, ograniczenia zaangażowania funduszy publicznych lub prawdopodobieństwa ich zaangażowania wobec sektora finansowego lub jej poszczególnych podmiotów, zapewnienia kontynuacji realizowanych przez zagrożony podmiot funkcji krytycznych, ochrony deponentów i inwestorów objętych systemem rekompensat oraz ochrony środków powierzonych podmiotowi przez jego klientów"2. Z drugiej strony jednak tak dotkliwe ograniczenie proceduralnych uprawnień i gwarancji uczestników postępowania administracyjnego może budzić wątpliwości z punktu widzenia art. 45 ust. 1 Konstytucji RP i art. 31 ust. 3 Konstytucji RP. W niniejszym artykule chciałabym przeanalizować wybrane przeze mnie pod kątem szczególnej istotności uprawnienia i obowiązki strony postępowania na gruncie ustawy o BFG i wykazać, że mimo pewnych potencjalnie zagrażających stronie postępowania przepisów, stanowią one środek proporcjonalny.

\section{PRZYCZYNY OGRANICZENIA PROCEDURALNYCH PRAW STRONY POSTĘPOWANIA W RESOLUTION}

Skutecznie prowadzona przymusowa restrukturyzacja powinna opierać się na dwóch zasadniczych cechach: szybkości postępowania oraz odpowiedniej koordynacji działań pomiędzy zaangażowanymi organami i podmiotami.

Po pierwsze, dyrektywa BRR stanowi w preambule, że ,,szybkie i skoordynowane działania są niezbędne w celu podtrzymania zaufania rynku i zminimalizowania efektu domina". Efekt domina, czy też inaczej efekt zarażania (ang. the contagion effect lub spillover effect), wyraża się w rozprzestrzenianiu się zakłóceń stabilności jednego banku na kolejne, powiązane z nim instytucje, a niekiedy, w szczególnych przypadkach również na cały sektor, także w skali

\footnotetext{
${ }^{2}$ Funkcje krytyczne rozumiane tutaj są, przez doktrynę, jako „czynności wykonywane na rzecz podmiotów trzecich, których zaprzestanie świadczenia prowadziłoby do zakłócenia w podaży usług o krytycznym znaczeniu dla funkcjonowania sfery realnej gospodarki oraz stabilności finansowej." - Por. Zimmernan [w:] Zawadzka i in. (red.) [2017: 175].
} 
międzynarodowej. Warto wspomnieć tutaj również o różnicy pomiędzy efektem zarażania a transferem ryzyka - ten pierwszy następuje w sposób nieprzewidywalny i gwałtowny, a liczba podmiotów nim objętych jest znaczna, a transfer ryzyka opiera się na uzasadnionych i skonkretyzowanych podstawach, w sposób przewidywalny i uporządkowany, najczęściej pomiędzy małą liczbą powiązanych ze sobą podmiotów [Kozińska 2018: 26]. Przyczyny ekonomiczne efektu zarażania mają oczywiście złożony charakter, natomiast w sytuacji zagrożenia stabilności banku kluczowe wydaje się być w tym kontekście zjawisko paniki bankowej, która może doprowadzić do bardzo szybkiego wzrostu potencjalnych strat instytucji bankowych [Gleeson i Guynn 2016: 5]. W sytuacji ujawnienia poważnego zagrożenia stabilności systemowo ważnego banku depozytariusze skłonni są do masowego wycofywania depozytów, nie tylko z instytucji bezpośrednio zagrożonej, a również - w wyniku niedostatecznych informacji $-\mathrm{z}$ innych, potencjalnie bezpiecznych banków. Powoduje to bardzo szybkie zakłócenia płynności całego sektora, a w konsekwencji rozprzestrzenianie się kryzysu.

Po drugie, dyrektywa BRR stanowi również, że uruchomienie procedury przymusowej restrukturyzacji powinno nastąpić w odpowiednim terminie - tj. zanim księgi rachunkowe instytucji finansowej wykażą niewypłacalność. Oznacza to, że nadrzędnym celem wszczęcia takiej procedury jest w rzeczywistości zachowanie ciągłości funkcji krytycznych zagrożonego podmiotu, co wymaga zdecydowanych i sprawnie skoordynowanych działań. Działania te opierać mają się na sprawnym współdziałaniu zaangażowanych organów, tj. w przypadku polskiej regulacji - przede wszystkim Komisji Nadzoru Finansowego, do której należy ocena spełnienia warunków wszczęcia przymusowej restrukturyzacji oraz Bankowego Funduszu Gwarancyjnego, który procedurę tę ma prowadzić. Ponadto, na mocy art. 103 ust. 6 ustawy o BFG - o decyzji przewidującej m.in. wszczęcie przymusowej restrukturyzacji informuje się również inne zainteresowane organy, m.in. Komisję Europejską czy Europejski Bank Centralny.

\section{WYŁĄCZENIE ZASADY OGÓLNEJ CZYNNEGO UDZIAŁU STRON}

W pierwszej kolejności przyjrzeć należy się wyłączeniu istotnej z punktu widzenia prawidłowości postępowania administracyjnego, czy też ujmowanego szerzej - prawa do obrony i prawa do procesu - zasady czynnego udziału stron (czy też inaczej: zasady wysłuchania stron). Art. 11 ust. 5 ustawy o BFG stanowi, że do decyzji wskazanych w art. 11 ust. 4 (tj. decyzji dotyczących wszczęcia i prowadzenia przymusowej restrukturyzacji, stosowania instrumentów przymusowej restrukturyzacji w stosunku do zagrożonych podmiotów oraz nakładania sankcji administracyjnych w ramach postępowania) nie stosuje się art. 10 k.p.a. Na mocy tego artykułu organy administracji publicznej obowiązane są zapewnić stro- 
nom czynny udział w każdym stadium postępowania, a przed wydaniem decyzji umożliwić im wypowiedzenie się co do zebranych dowodów, materiałów oraz zgłoszonych żądań.

$\mathrm{Z}$ zasadą czynnego udziału stron wiąże się obowiązek po stronie organu ustalenia kręgu osób posiadających interes prawny, a naruszenie tego rodzaju obowiązku może skutkować niezgodnością z fundamentalną zasadą prawdy materialnej [Malanowski [w:] Hauser i Wierzbowski (red.) 2017: 119]. By zachować postulowaną sprawność postępowania w sprawie przymusowej restrukturyzacji, obowiązek ten został zniesiony, a pojęcie strony postępowania skonkretyzowane.

Wyżej wymieniona zasada składa się z dwóch zasadniczych komponentów, na co wskazuje wykładnia omawianego artykułu [Adamiak [w:] Adamiak i Borkowski (red.) 2017: 96]. Po pierwsze, strona postępowania ma prawo do czynnego udziału w postępowaniu, tj. m.in. prawo do inicjowania postępowania, prawo do wypowiadania się co do treści żądania w każdym stadium postępowania oraz prawo do ustosunkowania się co do konkretnych dowodów i twierdzeń pojawiających się $\mathrm{w}$ ramach postępowania wyjaśniającego. Zasada ta materializuje się $\mathrm{w}$ formie czynnego uczestnictwa $\mathrm{w}$ postępowaniu wyjaśniającym poprzez uprawnienie do udziału w prawidłowym ustaleniu stanu faktycznego oraz prawnego sprawy. W przedmiocie tego aspektu wielokrotnie wypowiadał się zresztą Naczelny Sąd Administracyjny ${ }^{3}$.

Po drugie, dzięki zasadzie wyrażonej w art. 10 k.p.a. stronie przysługuje prawo do wypowiedzenia się $\mathrm{w}$ przedmiocie całego postępowania, tj. prawo do tzw. „ostatniego słowa” w postępowaniu. Prawo do wypowiedzenia się co do całości zgromadzonego materiału stanowi szansę dla strony, by skonfrontować własne stanowisko z ostatecznym stanowiskiem organu przed wydaniem decyzji organu kształtującej prawa i obowiązki strony.

Ograniczenie to wydaje się mieć uzasadnienie z punktu widzenia realizacji celów resolution. Należy przede wszystkim zwrócić tutaj uwagę na szczególną konstrukcję resolution $\mathrm{w}$ formie procedury administracyjnej. W klasycznym postępowaniu jurysdykcyjnym za moment wszczęcia postępowania uważa się umownie dokonanie przez organ pierwszej czynności wobec strony czy też pierwszą czynność podjętą w postępowaniu w ogóle ${ }^{4}$. W przypadku resolution

${ }^{3}$ Wyrok NSA z 14.06.2016 r., II OSK 2473/14: „Zasada czynnego udziału stron nakłada na organ administracji publicznej obowiązek zapewnienia stronom czynnego udziału w każdym stadium postępowania oraz obowiązek umożliwienia stronom wypowiedzenia się co do zebranych dowodów i materiałów oraz zgłoszonych żądań. Prawo czynnego udziału strony w postępowaniu, jako korelat obowiązku organu, obejmuje prawo do podejmowania czynności procesowych mających wpływ na ustalenie stanu faktycznego i prawnego sprawy administracyjnej”.

${ }^{4}$ Wyrok NSA z 22.04.1981 r., SA 1089/81 - „Datą wszczęcia postępowania administracyjnego może być przesłuchanie świadka, jako pierwsza czynność podjęta przez organ administracji $\mathrm{z}$ urzędu". 
wszczęcie przymusowej restrukturyzacji następuje w momencie doręczenia zagrożonemu podmiotowi decyzji wydanej przez Fundusz. Oznacza to więc, że postępowanie wkracza wtedy w kolejną fazę, w ramach której mogą zostać zastosowane poszczególne instrumenty przewidziane dla tej formy restrukturyzacji. Wynika z tego, że przyznanie stronie - tj. podmiotowi będącemu adresatem decyzji - praw do wypowiadania się i konfrontowania twierdzeń organów prowadzących postępowanie spowodowałoby znaczne przedłużenie postępowania, a więc uniemożliwiłoby realizację postulatu niezwłocznego działania.

\section{OGRANICZENIE PRAWA DO ODWOŁANIA SIĘ OD DECYZJI ORAZ MOŻLIWOŚCI UZYSKANIA ODSZKODOWANIA}

Zasada dwuinstancyjności postępowania wyrażona w art. 15 k.p.a., stanowiąca wprost, że postępowanie administracyjne jest dwuinstancyjne jest właściwie powtórzeniem zasady zawartej w art. 78 Konstytucji RP. Wskazane jest tam, że każda ze stron ma prawo do zaskarżania orzeczeń i decyzji wydanych w pierwszej instancji. Dopuszczalne jest natomiast ustawowe wprowadzenie wyjątków od tej zasady oraz modyfikacja trybu zaskarżania, co znalazło wyraz w art. 15 k.p.a., wskazującym, że przepis szczególny może ograniczać dwuinstancyjny charakter postępowania. Ograniczenia takie nie były zresztą szczególną rzadkością w postępowaniu, czego dowodem jest chociażby szczególny tryb kwestionowania decyzji wydanych przez ministra czy samorządowe kolegium odwoławcze w pierwszej instancji (stronie przysługuje wtedy wniosek o ponowne rozpatrzenie sprawy, mający charakter niedewolutywny).

W postępowaniu w sprawie przymusowej restrukturyzacji regulacja dotycząca zaskarżenia wydanej przez Fundusz decyzji wydaje się mieć szczególny wymiar dla strony postępowania z praktycznego punktu widzenia. Po pierwsze, od decyzji o wszczęciu postępowania w sprawie przymusowej restrukturyzacji odwołanie nie przysługuje w ogóle. Jedyna możliwość w przedmiocie zakwestionowania tej decyzji to wniesienie skargi do sądu administracyjnego. Po drugie, termin do wniesienia skargi został skrócony i wynosi jedynie 7 dni, w przeciwieństwie do podstawowej ogólnej regulacji z art. 53 p.p.s.a., na podstawie której termin ten wynosi 30 dni od dnia doręczenia skarżącemu rozstrzygnięcia $\mathrm{w}$ sprawie. Po trzecie, jedynym podmiotem uprawnionym do wniesienia takiej skargi w imieniu zagrożonej instytucji jest jej rada nadzorcza i jest to jedna z jej dwóch kompetencji, które nie zostają zawieszone $\mathrm{z}$ dniem wszczęcia przymusowej restrukturyzacji (obok prawa do powołania zarządu podmiotu w restrukturyzacji). Przyspieszone zostaje również postępowanie przed sądem administracyjnym i w przypadku skargi kasacyjnej - przed NSA. Po czwarte, sąd pozbawiony zostaje uprawnień kasatoryjnych przysługujących mu na mocy p.p.s.a, a ma 
prawo jedynie do stwierdzenia wydania decyzji z naruszeniem prawa. Powoduje to, że decyzja taka nie zostaje wyeliminowana $\mathrm{z}$ obrotu prawnego, natomiast będzie następnie mogła pełnić funkcję prejudykatu w cywilnym postępowaniu odszkodowawczym prowadzonym na podstawie art. $417^{1}$ k.c. Jest to zasadniczo jedyna możliwość rekompensaty negatywnych skutków wydania nieprawidłowej decyzji, ze względu na to, że na mocy art. 105 ust. 3 ustawy o BFG - wydanie decyzji niezgodnej z prawem nie wpływa na ważność czynności prawnych dokonanych na jej podstawie i nie stanowi przeszkody do prowadzenia przez Fundusz działań, gdyby wstrzymanie takich działań miało powodować poważne konsekwencje dla zagrożonego podmiotu. W końcu - ograniczona zostaje tutaj również wysokość odszkodowania, które może zostać uzyskane ze względu na niezgodność z prawem decyzji wydanej przez Fundusz. Na podstawie art. 105 ust. 4 i 5 - odpowiedzialność odszkodowawcza ponoszona przez Fundusz w przypadku wydania decyzji niezgodnej z prawem ogranicza się wyłącznie do wysokości poniesionej straty oraz do świadczenia pieniężnego.

Kwestią budzącą szczególne wątpliwości z punktu widzenia zgodności z Konstytucją RP uprawnień strony w postępowaniu jest paradoksalnie nie brak postępowania odwoławczego, gdyż tego rodzaju rozwiązanie jest zasadniczo znane postępowaniu administracyjnemu i służy jego - w wyjątkowych sytuacjach - usprawnieniu i przyspieszeniu 5 . Przedmiotem kontrowersji jest tutaj natomiast termin do wniesienia skargi do sądu administracyjnego. Decyzja o wszczęciu przymusowej restrukturyzacji przez Fundusz zostaje niezwłocznie doręczona jej adresatowi, a następnie uzasadnienie tej decyzji jest w ciągu 14 dni od dnia doręczenia sporządzane przez Fundusz i może zostać doręczone również drogą elektroniczną. Ten tryb postępowania został uregulowany jako najkrótszy $\mathrm{z}$ możliwych przewidzianych prawem administracyjnym [Zimmernam [w:] Zawadzka i in. (red.) 2017: 253]. Biorąc pod uwagę niezwykle złożony przedmiot postępowania i szczegółowość warunków, które muszą zostać spełnione, by przymusowa restrukturyzacja została wszczęta, taki termin może faktycznie utrudniać wyczerpujące i merytoryczne odniesienie się do rozstrzygnięcia i jego uzasadnienia, a tym samym uniemożliwiać skuteczne zakwestionowanie decyzji Funduszu.

Regulacja przewidująca, że sąd może jedynie stwierdzić wydanie decyzji niezgodnej z prawem oraz czynności podjęte na jej podstawie nie tracą swojej ważności wydaje się być zgodna z założeniami dyrektywy BRR. Stanowi ona w preambule, że ze względu na przede wszystkim konieczność szybkiego postępowania, jak i ze względu na ochronę praw osób trzecich, które w związku z podjętą mogły nabyć konkretne uprawnienia, powinno się ograniczyć wpływ

${ }^{5}$ Można tutaj przywołać chociażby przykład niezaskarżalności decyzji przewidzianych na podstawie Ustawy - Prawo wodne czy Ustawy - Prawo o szkolnictwie wyższym, Por. Adamiak [w: Adamiak i Borkowski 2017: 116-117]. 
możliwego odwołania na wykonalność decyzji. Problem pojawia się dopiero w przypadku odpowiedzialności odszkodowawczej. Należy zauważyć, że finansowe skutki procedury resolution mogą być odczuwalne dopiero po latach, a odpowiednie miarkowanie strat może być w przypadku nieco bardziej złożonych podmiotów znacznie utrudnione [Binder 2016: 47].

\section{WAZTPLIWOŚCI KONSTYTUCYJNE - ZASADA PROPORCJONALNOŚCI}

$\mathrm{Z}$ art. 31 ust. 3 Konstytucji RP wynika, że ograniczenia w zakresie korzystania z konstytucyjnych wolności i praw mogą być ustanawiane tylko w ustawie i tylko wtedy, gdy są konieczne w demokratycznym państwie dla jego bezpieczeństwa lub porządku publicznego, bądź dla ochrony środowiska, zdrowia i moralności publicznej, albo wolności i praw innych osób. Dodatkowo, ograniczenia nie mogą naruszać istoty wolności i praw. Według stwierdzeń Trybunału Konstytucyjnego [Wyrok TK z 09.06.1998 r., K 28/97, OTK 1998, Nr 4, poz. 50] - ograniczenia te muszą być zgodne z zasadą proporcjonalności, która stanowi, że środki stosowane przez ustawodawcę muszą być w stanie doprowadzić do zamierzonych celów, muszą być niezbędne dla ochrony interesu, z którym są powiązane oraz ich efekty muszą być w proporcji do ciężarów nakładanych na obywatela. Wynika z niej więc, uznawany przez autorów, nakaz przydatności, konieczności oraz proporcjonalności sensu stricte [Szydło [w:] Safjan i Bosek (red.), 2016: 791-806]. Przydatność, w tym kontekście, rozumiana będzie jako wzięcie pod uwagę i znajomość następstw społecznych ustanowienia i obowiązywania norm prawnych o określonej treści [Szydło [w:] Safjan i Bosek (red.), 2016: 792]. Konieczność z kolei, jako „skorzystanie ze środków jak najmniej uciążliwych dla podmiotów, których prawa lub wolności ulegną ograniczeniu" ". Badanie tej cechy polegać miałoby tutaj na weryfikacji przez odpowiedni organ, czy możliwe było zastosowanie takich środków, które miałyby charakter mniej dotkliwy dla objętych nimi podmiotów. Proporcjonalność sensu stricto jest zaś interpretowana jako, w dużym uproszczeniu, pewne porównanie wad i zalet danych regulacji i rachunek mający na celu zestawienie ze sobą ostatecznych korzyści i strat po stronie jej adresatów [Szydło [w:] Safjan i Bosek (red.), 2016: 799]. Ostateczne rozstrzygnięcie charakteru proporcjonalności ograniczeń praw strony przewidzianej przez ustawę o BFG wymagałoby więc (w przypadku hipotetycznej weryfikacji konstytucjonalności przepisów prawnych) przeprowadzenia testu proporcjonalności według wskazanych wyżej kryteriów.

Warto tutaj wspomnieć, że w kontekście ustawy o BFG - kontrowersje wzbudzić może ochrona interesu, a mianowicie w szczególności dookreślenie tego

${ }^{6}$ Autor przywołuje tutaj wyrok TK z dnia 11 maja 1999 r., K 13/98, OTK 1999, Nr 4, poz. 74 - Szydło [w:] Safjan i Bosek (red.), 2016: 796. 
pojęcia. Ustawa o BFG stanowi, że przymusowa restrukturyzacja może być wszczęta tylko wtedy, gdy działania wobec podmiotu krajowego są konieczne w interesie publicznym. Działanie w interesie publicznym zostało zdefiniowane w ustawie o BFG jako działanie konieczne do realizacji co najmniej jednego z celów przymusowej restrukturyzacji (m.in. utrzymanie stabilności finansowej, zapewnienie kontynuacji funkcji krytycznych, ochrona deponentów), a realizacja tych celów nie jest możliwa w ramach sprawowanego nadzoru lub postępowania upadłościowego. Interes publiczny na gruncie ustawy o BFG stanowi więc szczegółowe rozwinięcie komponentów konstytucyjnej zasady proporcjonalności.

Odrębną kwestią pozostaje tutaj również zgodność z art. 45 ust. 1 Konstytucji RP skróconego postępowania sądowego i ograniczenia terminu do wniesienia skargi do sądu administracyjnego. Jednym z elementów konstytucyjnej zasady jest tutaj prawo do uruchomienia postępowania przed sądem, na które składa się ukształtowanie przez prawo takich norm, które gwarantują skuteczne uruchomienie postępowania sądowego i uzyskanie w nim merytorycznego rozstrzygnięcia [Grzegorczyk i Weitz [w:] Safjan i Bosek (red.), 2016: 1111]. Siedmiodniowy termin na wniesienie skargi do sądu administracyjnego może być $\mathrm{w}$ tym kontekście znacząco dotkliwy dla strony i tym samym utrudniać jej prawidłowe odniesienie się do treści decyzji Funduszu.

\section{PODSUMOWANIE}

Jak zostało wskazane w treści mojego artykułu, prawa strony postępowania administracyjnego, jakim jest postępowanie w sprawie przymusowej restrukturyzacji doznają znacznych ograniczeń. Wyłączona zostaje zasada czynnego udziału stron, umożliwiająca stronie bycie wysłuchanym na każdym etapie postępowania, ograniczone zostaje prawo kwestionowania decyzji wydanej przez Fundusz oraz uzyskania na jej podstawie odszkodowania.

Warto zauważyć również, że przymusowa restrukturyzacja ukształtowana została jako środek ostateczny, wykorzystywany w szczególnie „kryzysowym” momencie, gdy inne środki nie przyniosą oczekiwanych rezultatów. Wszczęcie przymusowej restrukturyzacji jest również poprzedzone szerokimi konsultacjami pomiędzy organami zaangażowanymi $\mathrm{w}$ sieć bezpieczeństwa bankowego. $\mathrm{W}$ związku z tym powaga potencjalnego zagrożenia stabilności finansowej wydaje się uzasadniać szeroką ingerencję ustawodawcy w prawa strony postępowania administracyjnego. Postulat szybkości postępowania, który ma na celu uniknięcie negatywnych ekonomicznie zjawisk oraz rozprzestrzenianie się potencjalnego kryzysu finansowego powoduje, że zarówno udział strony, jak i terminy wyznaczone do jej działania w postępowaniu mogą ulec skróceniu. Problemem pozostaje jednak wciąż kwestia wykonalności decyzji i stwierdzenie 
jej niezgodności z prawem, co następnie będzie pełniło funkcję prejudykatu w postępowaniu odszkodowawczym. Jak zostało wspomniane powyżej, może tutaj pojawić się problem z oszacowaniem poniesionej straty, w szczególności w sytuacji, w której potencjalne straty strony postępowania (czy również innych interesariuszy, którym została przyznana legitymacja skargowa) mogą ujawnić się po długim czasie, obejmującym nawet kilka lat. Bez względu jednak na wątpliwości, które budzi omawiana przeze mnie regulacja, należy zauważyć, że póki przymusowa restrukturyzacja nie zostanie uruchomiona, rozważania mają charakter głównie teoretyczny, a prawdziwym wyzwaniem dla praktyków prawa będzie wszczęcie jej przez Bankowy Fundusz Gwarancyjny po raz pierwszy.

\section{BIBLIOGRAFIA}

Adamiak B., Borkowski J. (red.), 2017, Kodeks postępowania administracyjnego. Komentarz., Warszawa.

Band de O., Hartmann P., Alcalde J.L.P., 2015, Systemic Risk in Banking After the Great Financial Crisis, [w:] The Oxford Handbook of Banking, A.N. Berger, P. Molyneux, J.O.S. Wilson (red.), Oksford.

Binder J.H., 2016, The Position of Creditors under the BRRD, [w:] Memorial Volume for Leonidas Georgakopoulos, Ateny.

Bolzico J., Mascaro Y., Granata P., 2007, Practical Guidelines for Effective Bank Resolution, 2007, „Policy Research Working Paper”, $\mathrm{nr}$ 4389, [w:] https://openknowledge. worldbank.org/handle/10986/7548 [dostęp: 14.01.2018].

Dyrektywa Parlamentu Europejskiego i Rady 2014/59/UE z dnia 15 maja 2014 r. ustanawiająca ramy na potrzeby prowadzenia działań naprawczych oraz restrukturyzacji i uporządkowanej likwidacji w odniesieniu do instytucji kredytowych i firm inwestycyjnych oraz zmieniająca dyrektywę Rady 82/891/EWG i dyrektywy Parlamentu Europejskiego i Rady 2001/24/WE, 2002/47/WE, 2004/25/WE， 2005/56/WE， 2007/36/WE， 2011/35/UE, 2012/30/UE i 2013/36/EU oraz rozporządzenia Parlamentu Europejskiego i Rady (UE) nr 1093/2010 i (UE) nr 648/2012 (Dz.Urz. UE, L 173/190).

Gleeson S., Guynn R., 2016, Bank Resolution and Crisis Management. Law and Practice, Oksford.

Gronkiewicz-Waltz H, 2018, Przymusowa restrukturyzacja banków - resolution w: Prawo administracyjne wobec wspótczesnych wyzwań - Księga jubileuszowa dedykowana profesorowi Markowi Wierzbowskiemu, Warszawa 2018.

Gołaszewski P., 2017, [w]: Kodeks postepowania administracyjnego. Komentarz, R. Hauser, M. Wierzbowski (red.) Warszawa 2017.

Malanowski j., 2017, [w:] Kodeks postępowania administracyjnego. Komentarz, R. Hauser, M. Wierzbowski (red.), Warszawa 2017.

Hauser R., Wierzbowski M. (red.), 2017, Prawo o postępowaniu przed sąami administracyjnymi. Komentarz., Warszawa.

Key Attributes of Effective Resolution Regimes for Financial Institutions, 2014, Financial Stability Board, 2014 [w:] www.fsb.org/wp-content/uploads/r_111104cc.pdf [dostęp: 14.01.2018].

Konstytucja Rzeczypospolitej Polskiej z dnia 2 kwietnia 1997 r., Dz.U. 1997, nr 78, poz. 483. 
Kozińska M., 2018, Przymusowa restrukturyzacja banków w Unii Europejskiej, Warszawa.

Seeling S.A., 2006, Techniques of Bank Resolution, [w:] D.S. Hoelscher (red.), Bank Restructuring and Resolution, Nowy Jork.

Szydło M., 2016, [w:] M. Safjan, L. Bosek, (red.), Konstytucja RP. Tom I. Komentarz Art. 1-86, Warszawa.

Ustawa z dnia 14 czerwca 1960 r. Kodeks postępowania administracyjnego, Dz.U. 1960, nr 30, poz. 168.

Ustawa z dnia 23 kwietnia 1964 r. - Kodeks cywilny, Dz.U. 1964, nr 16, poz. 93.

Ustawa z dnia 30 sierpnia 2002 r. Prawo o postępowaniu przed sądami administracyjnymi, Dz.U. 2002, nr 153, poz. 1270.

Ustawa z dnia 10 czerwca 2016 r. o Bankowym Funduszu Gwarancyjnym, systemie gwarantowania depozytów oraz przymusowej restrukturyzacji, Dz.U. 2016, poz. 996.

Wyrok Naczelnego Sądu Administracyjnego z 22.04.1981 r., SA 1089/81.

Wyrok Trybunału Konstytucyjnego z 09.06.1998 r., K 28/97, OTK 1998, Nr 4, poz. 50.

Wyrok Naczelnego Sądu Administracyjnego z 14.06.2016 r., II OSK 2473/14.

Zimmerman P., 2017 [w:] P. Zawadzka, P. Zimmermann, R. Sura (red.), Ustawa o Bankowym Funduszu Gwarancyjnym, systemie gwarantowania depozytów oraz przymusowej restrukturyzacji. Komentarz, Warszawa.

\title{
ENGLISH TITLE: THE PARTY'S RIGHTS IN THE RESOLUTION PROCEDURE
}

\begin{abstract}
The article consists of the analysis of the party's rights in the resolution procedurę. This regulation, which was designed in the form of administrative proceedings, is dedicated to improve restructuring or liquidation of the compromised entities. Its aim is not only to possibly maximise the balance of the entity's assets, but also to involve public budget to a very minor extent. The cost of procedure should be born by the entities' shareholders and creditors. Resolution is treated as an ultimate measure and it should be introduced only when the other possible instruments will not be able to protect financial system against the crisis.

In the framework of Polish regulation the parties' rights were significantly restricted. The Act's provisions exclude the principle of active parties' participation and the possiblity to appeal against the decision. They also restrict the possibility of receiving compensation for incorrect decision and shorten deadlines to introduce proceedings against the decision before administrative court. The aim of the article is to analyse those restrictions in the light of resolution's goals and hypothetical incompatibility to Constitution of Poland.
\end{abstract}

Keywords: resolution, party, administrative proceedings, financial crisis. 